\title{
Article
}

\section{X-ray Irradiation-Induced Abnormal Development and DNA Damage in Phthorimaea operculella (Lepidoptera: Gelechiidae)}

\author{
Sun-Ran Cho, Minjun Kim, Eungyeong Shin, Hyun Kyung Kim, Hyun-Na Koo and Gil-Hah Kim * \\ Department of Plant Medicine, College of Agriculture, Life and Environment Sciences, \\ Chungbuk National University, Cheongju 28644, Korea; wonfight@naver.com (S.-R.C.); \\ kiricss1224@gmail.com (M.K.); s2ek04657@gmail.com (E.S.); nshk0917@hanmail.net (H.K.K.); \\ hyunnakoo@hanmail.net (H.-N.K.) \\ * Correspondence: khkim@chungbuk.ac.kr; Tel.: +82-43-261-2555; Fax: +82-43-271-4414
}

check for updates

Citation: Cho, S.-R.; Kim, M.; Shin, E.; Kim, H.K.; Koo, H.-N.; Kim, G.-H. $\mathrm{X}$-ray Irradiation-Induced Abnormal Development and DNA Damage in Phthorimaea operculella (Lepidoptera: Gelechiidae). Appl. Sci. 2021, 11, 5068 https://doi.org/10.3390/app 11115068

\section{Academic Editor:}

Spiridon Mantzoukas

Received: 13 May 2021

Accepted: 28 May 2021

Published: 30 May 2021

Publisher's Note: MDPI stays neutral with regard to jurisdictional claims in published maps and institutional affiliations.

Copyright: (c) 2021 by the authors. Licensee MDPI, Basel, Switzerland. This article is an open access article distributed under the terms and conditions of the Creative Commons Attribution (CC BY) license (https:// creativecommons.org/licenses/by/ $4.0 /)$.

\begin{abstract}
The potato tuber moth, Phthorimaea operculella (Zeller), is a destructive pest of Solanaceous crops. This study investigated the effects of X-ray irradiation on development, DNA damage and recovery in P. operculella. Eggs, larvae $\left({ }^{*} 3 \mathrm{rd}\right.$ and 5 th), pupae, and adults were irradiated with various doses of X-ray irradiation. Egg hatching was inhibited at $70 \mathrm{~Gy}$, and the pupation and adult emergence of 3rd-instar larvae were inhibited at $150 \mathrm{~Gy}$ and $70 \mathrm{~Gy}$, respectively. Some 5th-instar larvae pupated at $150 \mathrm{~Gy}$ but failed to emerge as adults at $150 \mathrm{~Gy}$. The adult emergence of pupae that spawned at $150 \mathrm{~Gy}$, but egg hatching of $F_{1}$ generation was completely inhibited. In addition, the adult emergence of irradiated-pupae was completely inhibited at $200 \mathrm{~Gy}$. Adults spawned at $150 \mathrm{~Gy}$, but the hatching of the $F_{1}$ generation was completely suppressed. The levels of DNA damage and repair in P. operculella adults were investigated using the alkaline comet assay. The results indicated that X-ray irradiation increased DNA damage in a dose-dependent manner and showed that DNA damage was repaired in a time-dependent manner. However, damage from a high radiation doses was not completely repaired. This result suggests that at least $150 \mathrm{~Gy}$ radiation should be used for the control P. operculella.
\end{abstract}

Keywords: Phthorimaea operculella; X-ray; abnormal development; DNA damage

\section{Introduction}

The potato tuber moth, Phthorimaea operculella (Zeller), is a major pest of Solanaceous crops, including potato, tomato, and eggplant [1-3]. P. operculella larvae are commonly known as 'potato tuber worms', and they inhabit plant growth sites and are found in tissues such as leaves, stems, and fruits $[4,5]$. P. operculella larvae cause problems mostly during the storage and distribution of agricultural commodities because they can reduce quantities and lower quality [6-8]. Secondary damage occurs in crops with wounds created by the larvae because fungi and bacteria grow in the wounds [9]. In addition, increased number of $P$. operculella are expected to occur in some regions of China and India due to climate change, so there is a need for a method to prevent massive damage caused by this pest during potato cultivation and storage [10].

P. operculella is regulated as a quarantine pest by the European and Mediterranean Plant Protection Organization (EPPO) and in Taiwan [11]. To control this insect pest, fumigants such as methyl bromide (MB), phosphine $\left(\mathrm{PH}_{3}\right)$, and ethanedinitrile (EDN) are used. However, MB was designated as an ozone layer-depleting substance in the Montreal Protocol, and its use has been banned worldwide. In addition to chemical methods, physical methods such as the application of extreme temperature, controlled atmospheric conditions, and irradiation have been employed as alternative methods [12,13].

Ionizing energy such as X-rays is being applied to quarantine pests overseas [14]. Whereas fumigation treatment requires a long treatment time and leaves pesticide residues behind, ionizing energy does not present these problems [15]. In addition, ionizing energy, 
including X-rays, cannot immediately kill insect pests but is instead aimed at preventing their reproduction by inducing abnormal development and sterility [16-25]. When an insect pest is irradiated with ionizing energy, the DNA is damaged, but the damaged DNA stops the cell cycle, and recovery is attempted [26]. If the degree of damage is low, recovery to a normal level will occur, but if the degree of damage is high, normal conditions cannot be restored $[18,22,23]$.

In this study, the effects of X-rays on the development and reproduction of $P$. operculella were investigated in each developmental stage. In addition, DNA damage and recovery were studied in P. operculella following the application of X-rays. Based on this approach, we aimed to provide basic data on the results of X-ray-based pest control techniques in agricultural products.

\section{Materials and Methods}

\subsection{Test Insects}

A susceptible strain of P. operculella was obtained from the National Institute of Highland Agriculture (Pyeongchang, Korea) in July 2011. P. operculella was reared on potato tubers (Solanum tuberosum) without exposure to any known pesticides in the laboratory. $P$. operculella were successively reared in a breeding cage ( 30 by 30 by $30 \mathrm{~cm}$ ), for more than 9 years and were provided with potato tubers as food under the following conditions: $25 \pm 2{ }^{\circ} \mathrm{C}, 55 \pm 5 \%$, and a $16 \mathrm{~L}: 8 \mathrm{D}$ photoperiod cycle.

\subsection{X-ray Irradiation}

X-ray irradiation in air was conducted at EB-Tech Co., Ltd. (Daejeon, Republic of Korea) using a high-energy linear accelerator (UEL V10S, 7.5 MeV, $1 \mathrm{~mA}, 10 \mathrm{Kw}$ ). Target doses were monitored by dosimetry with an alanine pellet dosimeter (ES 200-2106, Bruker Biospin Co., Billerica, MA, USA). The target doses were set at 10, 30, 50, 70, 100, 150, and 200 Gy and were measured using a radiochromic film dosimeter (GEXGAF3002DS, USA) [ISO/ASTM512752004(E)]. The range of absorbed irradiation doses is shown in Figure 1.

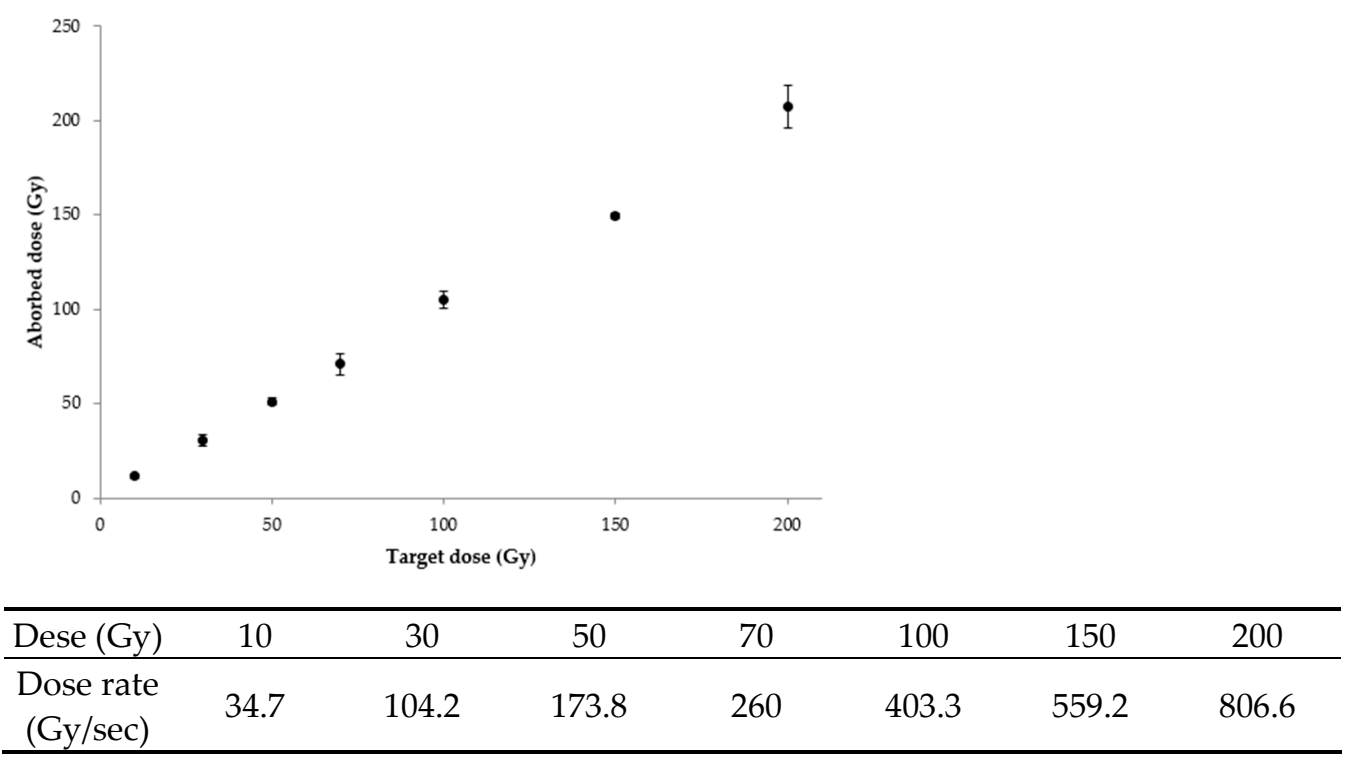

Figure 1. X-ray dosimetry.

Thirty female and thirty male P. operculella adults were placed in a breeding cage $(30 \times 30 \times 60 \mathrm{~cm})$ containing cotton soaked in a sugar solution $(5 \%)$ with coarse filter paper attached to the ceiling. They were permitted to lay eggs for $12 \mathrm{~h}$. The filter paper with attached eggs ( $0-12 \mathrm{~h}$ old) was then exposed to X-ray irradiation. Ten P. operculella larvae (3rd and 5th instars) were placed in a plastic Petri dish $(\varnothing 9 \times 4 \mathrm{~cm})$ with a potato tuber $(5 \times 1 \mathrm{~cm})$ and exposed to X-ray irradiation. Ten P. operculella pupae (less than 1 day 
after pupation) were placed in a plastic Petri dish $(\varnothing 9 \times 4 \mathrm{~cm})$ and exposed to X-ray irradiation. Ten P. operculella adults ( 5 females and 5 males, $0-24 \mathrm{~h}$ after emergence) were separately placed in circular plastic cages $(\varnothing 9 \times 8 \mathrm{~cm})$ and exposed to X-ray irradiation. To investigate the lethal effects on various developmental stages, we studied the rates of egg hatching and emergence suppression. The rate of egg hatching was recorded in X-rayirradiated eggs. In X-ray-irradiated 3rd-instar larvae, the pupation rate, adult emergence rate, larval period, and larval mortality were recorded. In X-ray-irradiated 5th-instar larvae, the pupation rate, adult emergence rate, larval period, larval mortality, and newly emerged adult longevity were recorded. In X-ray-irradiated pupae, the rate of new adult emergence and the longevity of newly emerged adults were recorded. Furthermore, the fecundity and $F_{1}$ egg hatchability were recorded that adults emerged and copulated successfully from the irradiated pupae. In X-ray-irradiated adults (female and males), the longevity of irradiated adults, and the fecundity and $F_{1}$ egg hatchability were recorded. Trials on the different stages of $P$. operculella were performed with three replicates.

\subsection{DNA Comet Assays}

DNA damage in P. operculella female adults was determined under alkaline conditions using the Comet Assay Kit from Trevigen (Gaithersburg, MD, USA) according to Yun et al. [19]. After X-ray irradiation, females of P. operculella adults were homogenized. The images were analyzed using CASP software (Comet Assay Software Project 1.2.2). At least 100 comets were analyzed from each sample. All experiments were performed three times.

\subsection{Recovery of Damaged DNA}

After X-ray irradiation, female P. operculella adults were sampled at 5, 24, 72, 144, and $212 \mathrm{~h}$, and the differences in DNA damage and DNA repair were investigated using the comet assay. The comet assay was performed in the same way as the DNA damage assay; 100 cells from each sample were randomly selected for observation, and the tail moment was measured using CASP software. Tail length/(tail length + head length) ratios were compared, and the degrees of DNA damage and recovery compared to untreated DNA were evaluated. All experiments were performed three times.

\subsection{Statistical Analysis}

Data were recorded and transformed to arcsine square-root values for the analysis of variance (ANOVA). Treatment means were compared and separated by Tukey's studentized range test at $P=0.05$. Effective dose (ED) values for inhibition in different developmental stages were considered to be significantly different from one another when the $95 \%$ confidence limits failed to overlap. All statistical analyses were conducted using SAS ver. 9.4 [27].

\section{Results}

\subsection{Effect of X-ray Irradiation on Each Developmental Stages of P. operculella}

The effects of X-ray irradiation on the eggs are shown in Table 1 . Hatchability decreased as the irradiation dose increased, and hatching was completely suppressed above $70 \mathrm{~Gy}$. The median $\mathrm{ED}\left(\mathrm{ED}_{50}\right)$ value for the X-ray irradiation of eggs was 6.6.

The effects of X-ray irradiation on the 3rd- and 5th-instar larvae are shown in Tables 2 and 3, respectively. When 3rd-instar larvae were irradiated at $150 \mathrm{~Gy}$, pupation was completely suppressed. At doses of 70 Gy and above, no adult emergence was observed. The $\mathrm{ED}_{50}$ values for the pupation, emergence, and mortality of the 3rd-instar P. operculella were $30.3 \mathrm{~Gy}, 38.8 \mathrm{~Gy}$, and $74.7 \mathrm{~Gy}$, respectively. When 5th-instar larvae were irradiated at $150 \mathrm{~Gy}$, although some larvae pupated, they did not emerge to adults. The adult longevity of P. operculella when irradiated at $100 \mathrm{~Gy}$ was significantly different than that of the untreated control moths. Additionally, the $\mathrm{ED}_{50}$ values for the pupation, 
emergence, and mortality of 5th-instar P. operculella larvae were $189.6 \mathrm{~Gy}, 46.8 \mathrm{~Gy}$, and $194.7 \mathrm{~Gy}$, respectively.

Table 1. Effect of X-ray irradiation on hatchability in P. operculella eggs.

\begin{tabular}{ccc}
\hline Dose & $\mathbf{n}$ & Hatchability \\
\cline { 1 - 1 }$(\mathrm{Gy})$ & & $\mathbf{( \% )}$ (Mean \pm SD) \\
\hline 100 & 800 & -1 \\
70 & 827 & $0.0 \pm 0.0 \mathrm{c}^{2}$ \\
50 & 667 & $0.3 \pm 0.3 \mathrm{c}$ \\
30 & 832 & $2.3 \pm 1.1 \mathrm{c}$ \\
10 & 797 & $28.5 \pm 1.8 \mathrm{~b}$ \\
0 & 686 & $98.0 \pm 1.3 \mathrm{a}$ \\
\hline ED & - & $6.6(4.5-8.3)$ \\
$(G y)$ & - & $37.0(27.7-62.6)$ \\
ED99 & - & \\
(Gy) & & \\
\hline
\end{tabular}

${ }^{1}$ Not determined ${ }^{2}$ Different letter indicate statistically significant differences among doses.

Table 2. Effect of X-ray irradiation on pupation, emergence, larval period, and mortality in P. operculella 3rd instar larvae.

\begin{tabular}{|c|c|c|c|c|c|}
\hline Dose & & Pupation & Emergence & Larval Period & Mortality \\
\hline (Gy) & $\mathbf{n}$ & $(\%)($ Mean \pm SD) & $(\%)($ Mean \pm SD) & $\begin{array}{c}\text { (day) } \\
(\text { Mean } \pm \text { SD) }\end{array}$ & $(\%)($ Mean \pm SD) \\
\hline 150 & 30 & $0.0 \pm 0.0 \mathrm{~d}^{1}$ & $0.0 \pm 0.0 \mathrm{c}$ & -2 & $100.0 \pm 0.0 \mathrm{~d}$ \\
\hline 100 & 30 & $6.7 \pm 5.8 \mathrm{~d}$ & $0.0 \pm 0.0 \mathrm{c}$ & $17.7 \pm 0.6 b$ & $93.3 \pm 5.8 \mathrm{~d}$ \\
\hline 70 & 30 & $13.3 \pm 5.8 \mathrm{~d}$ & $0.0 \pm 0.0 \mathrm{c}$ & $16.6 \pm 1.5 \mathrm{~b}$ & $86.7 \pm 5.8 \mathrm{~d}$ \\
\hline 50 & 30 & $30.0 \pm 0.0 c$ & $33.3 \pm 33.3 \mathrm{bc}$ & $10.9 \pm 0.3 \mathrm{a}$ & $70.0 \pm 0.0 c$ \\
\hline 30 & 30 & $46.7 \pm 11.5 b$ & $66.7 \pm 28.9 \mathrm{ab}$ & $9.8 \pm 0.2 \mathrm{a}$ & $53.3 \pm 11.5 b$ \\
\hline 0 & 30 & $100.0 \pm 0.0 \mathrm{a}$ & $86.7 \pm 15.3 \mathrm{a}$ & $9.4 \pm 0.2 \mathrm{a}$ & $0.0 \pm 0.0 \mathrm{a}$ \\
\hline $\mathrm{ED}_{50}$ & & 30.3 & 38.8 & & 74.7 \\
\hline (Gy) & & $(24.9-34.8)$ & (33.3-42.7) & - & $(71.6-78.0)$ \\
\hline ED99 & & 174.6 & 88.7 & & 130.4 \\
\hline$(\mathrm{Gy})$ & & $(137.3-252.0)$ & $(75.8-118.1)$ & - & (119.1-147.4) \\
\hline
\end{tabular}

${ }^{1}$ Different letter indicate statistically significant differences among doses ${ }^{2}$ Not determined.

Table 3. Effect of X-ray irradiation on pupation, emergence, larval period, mortality, and adult longevity in P. operculella 5th instar larvae.

\begin{tabular}{|c|c|c|c|c|c|c|}
\hline Dose & $\mathbf{n}$ & Pupation & Emergence & Larval Period & Mortality & Adult Longevity \\
\hline$(\mathrm{Gy})$ & 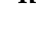 & $(\%)($ Mean \pm SD) & $(\%)($ Mean \pm SD $)$ & $($ day $)($ Mean \pm SD) & $(\%)($ Mean \pm SD) & $($ day $)($ Mean $\pm S D)$ \\
\hline 150 & 30 & $66.7 \pm 5.8 b c^{1}$ & $0.0 \pm 0.0 \mathrm{~d}$ & $4.2 \pm 0.2 b$ & $33.3 \pm 5.8 c$ & -2 \\
\hline 100 & 30 & $80.0 \pm 10.0 \mathrm{~b}$ & $22.2 \pm 17.9 \mathrm{c}$ & $3.4 \pm 0.1 \mathrm{a}$ & $16.7 \pm 5.8 b$ & $3.8 \pm 1.3 b$ \\
\hline 70 & 30 & $86.7 \pm 5.8 \mathrm{ab}$ & $38.9 \pm 14.7 \mathrm{bc}$ & $3.2 \pm 0.1 \mathrm{a}$ & $13.3 \pm 5.8 b$ & $8.4 \pm 0.8 \mathrm{a}$ \\
\hline 50 & 30 & $100.0 \pm 0.0 \mathrm{a}$ & $60.0 \pm 17.3 \mathrm{ab}$ & $3.2 \pm 0.1 \mathrm{a}$ & $0.0 \pm 0.0 \mathrm{a}$ & $9.0 \pm 0.8 \mathrm{a}$ \\
\hline 30 & 30 & $100.0 \pm 0.0 \mathrm{a}$ & $83.3 \pm 11.5 a$ & $3.1 \pm 0.1 \mathrm{a}$ & $0.0 \pm 0.0 \mathrm{a}$ & $9.8 \pm 0.5 a$ \\
\hline 0 & 30 & $100.0 \pm 0.0 \mathrm{a}$ & $93.3 \pm 5.8 \mathrm{a}$ & $3.3 \pm 0.1 \mathrm{a}$ & $0.0 \pm 0.0 \mathrm{a}$ & $9.9 \pm 0.5 a$ \\
\hline $\begin{array}{l}\mathrm{ED}_{50} \\
(\mathrm{~Gy})\end{array}$ & & $\begin{array}{c}189.6 \\
(160.0-249.1)\end{array}$ & $\begin{array}{c}46.8 \\
(43.0-50.4)\end{array}$ & - & $\begin{array}{c}194.7 \\
(163.3-259.4)\end{array}$ & - \\
\hline $\begin{array}{l}\mathrm{ED}_{99} \\
\text { (Gy) }\end{array}$ & & $\begin{array}{c}467.7 \\
(331.0-847.6)\end{array}$ & $\begin{array}{c}162.4 \\
(145.6-185.6)\end{array}$ & - & $\begin{array}{c}480.4 \\
(336.8-891.2)\end{array}$ & - \\
\hline
\end{tabular}

${ }^{1}$ Different letter indicate statistically significant differences among doses. ${ }^{2}$ Not determined. 
The effects of X-ray irradiation on the pupae are shown in Table 4. At 200 Gy, no adult emergence was observed. The adult longevity of females and males and the fecundity of females decreased with increasing $X$-ray doses. At $150 \mathrm{~Gy}, F_{1}$ eggs did not hatch Additionally, the $\mathrm{ED}_{50}$ values for the emergence and $F_{1}$ egg hatchability of the P. operculella pupae were $73.1 \mathrm{~Gy}$ and $41.0 \mathrm{~Gy}$, respectively.

Table 4. Effect of X-ray irradiation on emergence, adult longevity, fecundity, and hatchability in P. operculella pupae.

\begin{tabular}{|c|c|c|c|c|c|c|}
\hline Dose & $\mathbf{n}$ & Emergence & Adult Longevity & Adult Longevity & No. Eggs & Hatchability \\
\hline (Gy) & & $(\%)($ Mean \pm SD) & $\begin{array}{c}(\stackrel{+}{ }, \text { day) } \\
\text { (Mean } \pm \text { SD) }\end{array}$ & $\begin{array}{c}\left(\sigma^{7}, \text { day }\right) \\
(\text { Mean } \pm \text { SD) }\end{array}$ & $\begin{array}{c}(\text { (o/total) } \\
(\text { Mean } \pm \text { SD) }\end{array}$ & $\begin{array}{c}(\%)\left(F_{1}\right) \\
(\text { Mean } \pm \text { SD) }\end{array}$ \\
\hline 200 & 30 & $0.0 \pm 0.0 c^{1}$ & -2 & - & - & - \\
\hline 150 & 30 & $15.6 \pm 12.6 c$ & $2.5 \pm 0.2 \mathrm{c}$ & $2.4 \pm 0.5 c$ & $5.2 \pm 1.0 \mathrm{~b}$ & $0.0 \pm 0.0 c$ \\
\hline 100 & 30 & $42.2 \pm 16.8 b$ & $6.5 \pm 0.3 b$ & $7.1 \pm 0.1 b$ & $9.2 \pm 1.3 b$ & $4.5 \pm 3.8 c$ \\
\hline 50 & 30 & $67.8 \pm 5.1 b$ & $7.7 \pm 0.5 b$ & $9.1 \pm 0.6 \mathrm{a}$ & $19.2 \pm 1.5 b$ & $35.5 \pm 4.8 b$ \\
\hline 0 & 30 & $98.9 \pm 1.9 \mathrm{a}$ & $9.9 \pm 0.3 \mathrm{a}$ & $9.4 \pm 0.3 a$ & $62.3 \pm 4.6 \mathrm{a}$ & $99.3 \pm 0.5 a$ \\
\hline $\begin{array}{l}\mathrm{ED}_{50} \\
\text { (Gy) }\end{array}$ & & $\begin{array}{c}73.1 \\
(62.6-82.3)\end{array}$ & - & - & - & $\begin{array}{c}41.0 \\
(32.8-44.5)\end{array}$ \\
\hline $\begin{array}{l}\mathrm{ED}_{99} \\
\text { (Gy) }\end{array}$ & & $\begin{array}{c}200.2 \\
(179.1-231.4)\end{array}$ & - & - & - & $\begin{array}{c}145.0 \\
(129.0-167.6)\end{array}$ \\
\hline
\end{tabular}

${ }^{1}$ Different letters indicate statistically significant differences among doses ${ }^{2}$ Not determined.

The effects of X-ray irradiation on the adults are shown in Table 5. The adult longevity of $P$. operculella irradiated at any dose was not significantly different from that of the untreated control moths. However, fecundity and $F_{1}$ egg hatchability decreased with increasing X-ray doses. At $150 \mathrm{~Gy}$, no eggs hatched. The $\mathrm{ED}_{50}$ value for the $F_{1}$ egg hatchability of $P$. operculella adults was 32.9 Gy.

Table 5. Effect of X-ray irradiation on adult longevity, fecundity, and hatchability in P. operculella adults.

\begin{tabular}{|c|c|c|c|c|c|}
\hline Dose & $\mathbf{n}$ & Adult Longevity & Adult Longevity & No. Eggs & Hatchability \\
\hline (Gy) & & $\begin{array}{c}(\stackrel{+}{ }, \text { day) } \\
(\text { Mean } \pm \text { SD) }\end{array}$ & $\begin{array}{c}\left(\sigma^{7}, \text { day }\right) \\
(\text { Mean } \pm \text { SD })\end{array}$ & $\begin{array}{c}\text { (o/total) } \\
(\text { Mean } \pm \text { SD) }\end{array}$ & $(\%)($ Mean \pm SD) \\
\hline 200 & 30 & $9.9 \pm 0.4 \mathrm{a}^{1}$ & $9.8 \pm 0.2 \mathrm{a}$ & $5.3 \pm 0.5 \mathrm{~d}$ & $0.0 \pm 0.0 \mathrm{c}$ \\
\hline 150 & 30 & $10.0 \pm 0.5 a$ & $9.8 \pm 0.4 \mathrm{a}$ & $9.4 \pm 5.0 \mathrm{~d}$ & $0.0 \pm 0.0 \mathrm{c}$ \\
\hline 100 & 30 & $9.9 \pm 0.4 a$ & $9.5 \pm 0.2 \mathrm{a}$ & $21.0 \pm 2.3 c$ & $16.9 \pm 7.4 b$ \\
\hline 50 & 30 & $10.3 \pm 0.1 \mathrm{a}$ & $10.2 \pm 0.4 a$ & $34.7 \pm 2.4 b$ & $20.5 \pm 1.6 b$ \\
\hline 0 & 30 & $10.0 \pm 0.1 \mathrm{a}$ & $9.6 \pm 0.2 \mathrm{a}$ & $57.5 \pm 6.3 a$ & $98.8 \pm 1.1 \mathrm{a}$ \\
\hline $\begin{array}{l}\mathrm{ED}_{50} \\
\text { (Gy) }\end{array}$ & & -2 & - & - & $32.9(26.0-39.5)$ \\
\hline $\begin{array}{l}\mathrm{ED}_{99} \\
\text { (Gy) }\end{array}$ & & - & - & - & $177.7(139.8-247.8)$ \\
\hline
\end{tabular}

${ }^{1}$ Different letters indicate statistically significant differences among doses ${ }^{2}$ Not determined.

\subsection{Effects of X-ray Irradiation on DNA Damage and Repair}

DNA damage was evaluated in P. operculella adults after $5 \mathrm{~h}$ of X-ray irradiation using a DNA comet assay. Comet images for cells obtained from P. operculella adults are presented in Figure 2. Untreated cells showed a round shape with a very small tail in comet images, indicating little or no DNA damage; on the other hand, the comet tail lengths of X-rayirradiated cells increased a dose-dependent manner. At doses of $100 \mathrm{~Gy}$ and above, most of the comet tails were long, but comets without a long tail were also frequently observed (Figure 2A). The results of calculations based on the observations are portrayed in graphs (Figure 2B). The increase in the tail moment observed in the comet assay indicated that DNA damage increased as the $\mathrm{X}$-ray dose increased. 
Thereafter, to conduct a time-series analysis of the repair of DNA damage induced by X-ray irradiation, a comet assay was carried out using P. operculella adults. Cells from P. operculella adults were sampled 5, 24, 72, 144, and $212 \mathrm{~h}$ after X-ray irradiation $(0,50,100$, and 150 Gy) and analyzed under alkaline conditions using the Comet Assay Kit. Frequency histograms of the ratios of individual cells are shown in Figure 3. The increase in the frequency of ratios close to one associated with an increasing radiation dose after $5 \mathrm{~h}$ of $\mathrm{X}$-ray irradiation indicated increased DNA damage. At $212 \mathrm{~h}$ after X-ray irradiation, the frequency of the ratios observed under a 50 Gy irradiation dose did not indicate a level of repair, similar to that in the control.
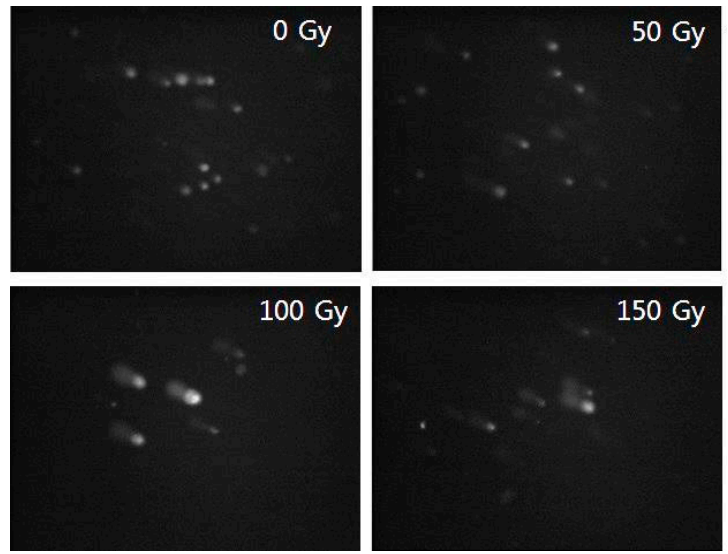

(A)

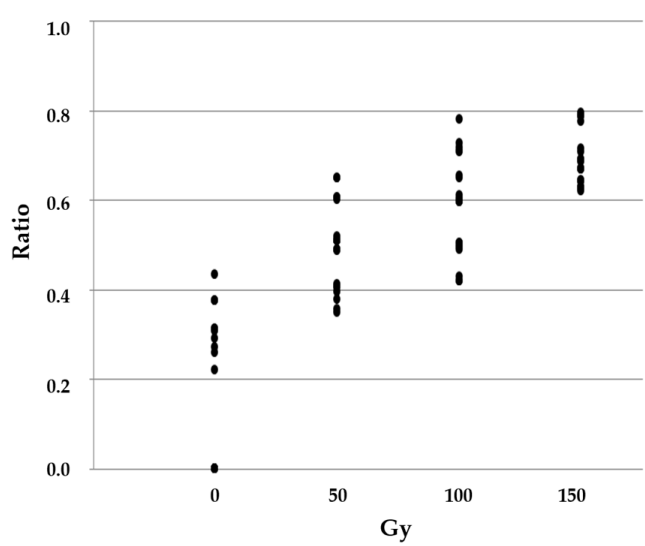

(B)

Figure 2. Comet assay of X-ray-induced DNA damage in P. operculella adults. The cells were harvested $5 \mathrm{~h}$ after $P$. operculella irradiation and analyzed under alkaline conditions using a Comet Assay Kit. (A) representative images of comets from P. operculella adults treated with X-ray irradiation at different doses. (B) graphic depiction of the calculated tail length from the analysis of alkaline comet assays. Data are shown for a representative experiment, in which at least 100 comets were quantified for each sample. Ratio, the percentage of fluorescence in the damaged area relative to overall luminance, including intact DNA (head) and the damaged area (tail) of a comet image. The X-axis represents the Gy, and the Y-axis represents the ratio.
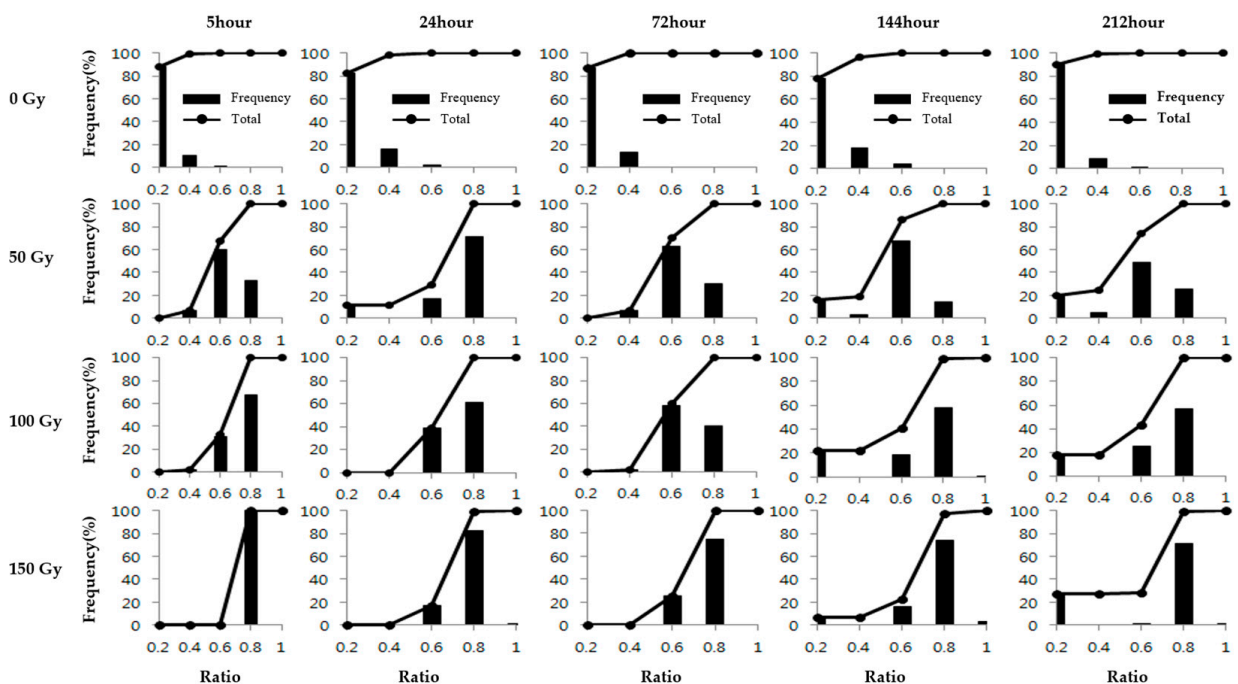

Figure 3. Frequency histogram of the parameter ratio at different time points before and after X-ray irradiation with various doses. The cells of P. operculella adults were harvested 5, 24, 72, 144, and $212 \mathrm{~h}$ after X-ray irradiation (0, 50, 100, and 150 Gy) and analyzed under alkaline conditions using a Comet Assay Kit. Ratio, the percentage of fluorescence in the damaged area relative to overall luminance, including intact DNA (head) and the damaged area (tail) of a comet image. The X-axis represents the ratio, and the Y-axis represents the frequency (\%). 


\section{Discussion}

These results demonstrated that the suppression of the development and reproduction of $P$. operculella increased with increasing X-ray doses. The most radiotolerant stages were pupae and adults, and the most radiosensitive stage was eggs. Similar to our findings, Kim et al. [28] reported that all stages of Helicoverpa armigera and its reproduction were inhibited by X-ray irradiation. In the present study, the hatching rate of the $F_{1}$ generation was investigated for pupae and adults, which means that the pupae and adults are generally studied to be more radiotolerant than the eggs and larvae [17-19]. Moreover, the population of emerged adults from the irradiated eggs and larvae was smaller than the irradiated pupae and adults. In addition, the emerged adults (female and male) were difficult to successfully copulated that the mating timing of female and male are not right. So, the results were difficult to investigate until the next generation.

While the research on the effects of ionizing energy on P. operculella following X-ray irradiation is insufficient, many studies have been performed on gamma-rays [29-33]. Although gamma-irradiation was not performed in this study, Mahto et al. [33] reported that the gamma-irradiation of the eggs and larvae of P. operculella at $120 \mathrm{~Gy}$ inhibited adult emergence and that emerged adults were deformed following gamma-irradiation at 80 Gy. In addition, Rananavare et al. [29] reported that P. operculella male adults irradiated with gamma-rays at $500 \mathrm{~Gy}$ showed no difference in mating ability from normal adults. However, other authors reported that the mating ability and frequency of mating decreased under $25 \mathrm{~Gy}$ of gamma-irradiation, and at $45 \mathrm{~Gy}$, the sterility of P. operculella male adults was $91 \%$ [31]. In addition, Haiba et al. [30,32] suggested that 150 Gy of gamma-irradiation should be applied to completely control P. operculella. When X-ray irradiation was applied to the pupae, the lifespan of newly emerged adults was shortened as the dose increased. This result was similar to the results of a study on gamma rays [33].

The comet assay is likely to be used in genotoxicology and biological monitoring studies to detect DNA damage under various pest control strategies [34]. In this study, X-ray irradiation was shown to induce DNA damage in P. operculella adults. The induction of DNA damage in insect pests irradiated with ionizing energy has also been observed in previous studies [17-20,23,35,36]. Yun et al. [19] reported that DNA damage in Spodoptera litura was not complete at electron beam irradiation doses of $100 \mathrm{~Gy}$ and above. However, the frequency of the ratios recorded at 30 and 50 Gy indicated repair to almost the same level observed in the control (0 Gy). In this study, DNA damage was not completely repaired $212 \mathrm{~h}$ after irradiation at a dose of $150 \mathrm{~Gy}$ or above. In addition, at doses of 50 and $100 \mathrm{~Gy}$, irradiated adults were not repaired at $0 \mathrm{~Gy}$. Yun et al. [19] confirmed that DNA damage caused by low-dose irradiation (30 and $50 \mathrm{~Gy}$ ) was repaired by multiple DNA repair systems and did not affect the hatchability of the $F_{1}$ adults when irradiation was performed at low doses. In this study, the induction of DNA damage in P. operculella adults by X-ray irradiation was confirmed only in females. However, according to the results reported in female and male $H$. armigera adults exposed to gamma-irradiation, females showed higher radiotolerance than males, as males exhibited longer tail moments than females [20].

In addition, only the susceptibility of P. operculella to X-rays was evaluated, and it is still necessary to perform an empirical evaluation, as in previous studies [21,24,25,37,38]. At quarantine sites, empirical tests for radiotolerant stages should be carried out, excluding inspection for pupal and adult insects that can be seen with the naked eye [39]. Taken together, the results of this study suggest that radiation treatment with at least 150 Gy could be required to control $P$. operculella.

\section{Conclusions}

The results of this study suggest that radiation treatment with at least 150 Gy could be required to control $P$. operculella. 
Author Contributions: Conceptualization, G.-H.K.; methodology, M.K. and E.S.; investigation, S.-R.C. and M.K; data curation, H.-N.K. and H.K.K.; writing-original draft preparation, S.-R.C.; writing-review and editing, H.-N.K. and G.-H.K.; supervision, G.-H.K. All authors have read and agreed to the published version of the manuscript.

Funding: This work was financially supported by the Research Year of Chungbuk National University in 2021.

Institutional Review Board Statement: Not applicable.

Informed Consent Statement: Not applicable.

Data Availability Statement: The data presented in this study are available on request from the corresponding author.

Conflicts of Interest: The authors declare no conflict of interest.

\section{References}

1. Gilboa, S.; Podoler, H. Population dynamics of the potato tuber moth on processing tomatoes in Israel. Entomol. Exp. Appl. 1994, 72, 197-206. [CrossRef]

2. Kirkham, R. Potatoes. In Horticulture Australia; Coombs, B., Ed.; Khai Wah-Ferco Pty. Ltd.: Singapore, $1995 ;$ pp. $250-256$.

3. Van Vuuren, J.J.; Bennett, A.; Bennett, A.L. Oviposition site preferences of potato tuber moth, Phthorimaea operculella (Zeller) (Lepidoptera: Gelechiidae), a pest on tobacco, Nicotiana tabacum L. (Solanaceae). Afr. Entomol. 1998, 6, 177-183.

4. Rothschild, G.H.L. The potato moth-An adaptable pest of short-term cropping systems. In The Ecology of Exotic Animals and Plants; Kitching, R.L., Ed.; John Wiley: Brisbane, Australia, 1986; pp. 144-462.

5. Fenemore, P.G. Host-plant location and selection by adult moth, Phthorimaea operculella Zell. (Lepidoptera: Gelechiidae) a review. J. Insect Physiol. 1988, 3, 175-177. [CrossRef]

6. Gelernter, W.D.; Trumble, J.T. Factors in the success and failure of microbial insecticides in vegetable crops. Integr. Pest. Manage. Rev. 1999, 4, 301-306. [CrossRef]

7. Jansky, S.H.; Jin, L.P.; Xie, K.Y.; Xie, C.H.; Spooner, D.M. Potato production and breeding in China. Potato Res. 2009, 52, 57-65. [CrossRef]

8. Rondon, S.I. The potato tuberworm: A literature review of its biology, ecology, and control. Am. J. Potato Res. 2010, 87, 149-166. [CrossRef]

9. Hanafi, A. Integrated pest management of potato tuber moth in field and storage. Potato Res. 1999, 42, 373-380. [CrossRef]

10. Jung, J.M.; Lee, S.G.; Kim, K.H.; Jeon, S.W.; Jung, S.; Lee, W.H. The potential distribution of the potato tuber moth (Phthorimaea operculella) based on climate and host availability of potato. Agronomy 2020, 10, 12. [CrossRef]

11. EPPO. Available online: http://www.eppo.int/MEETINGS/2015_meetings/wp_ppp.htm (accessed on 27 May 2015).

12. Heather, N.W.; Hallman, G.J. Pest Management and Phytosanitary Trade Barriers; CABI International: Wallingford, Oxfordshire, UK, 2008; pp. 132-152.

13. Ibrahim, R.A.; Al-Ahmadi, S.S. Utilization of ozone to control potato tuber moth, Phthorimaea operculella (Lepidoptera: Gelechiidae), in storage. Afr. Entomol. 2014, 22, 330-336. [CrossRef]

14. Follett, P.A. Irradiation to control insects in fruits and vegetables for export from Hawaii. Radiat. Phys. Chem. 2004, 71, 163-166. [CrossRef]

15. Osouli, S.; Ziale, F.; Nejad, K.H.I.; Moghaddam, M. Appli-cation of gamma irradiation on egg, active and quiescence stages of Tetranycus urticae Koch as a quarantine tretment of cut flower. Radiat. Phys. Chem. 2013, 90, 111-119. [CrossRef]

16. Moon, S.R.; Son, B.K.; Yang, J.O.; Woo, J.S.; Yoon, C.M.; Kim, G.H. Effect of Electron-beam Irradiation on Development and Reproduction of Bemisia tabaci, Myzus persicae, Plutella xylostella and Tetranychus urticae. Kor. J. Appl. Entomol. 2010, 49, 129-137. [CrossRef]

17. Koo, H.N.; Yoon, S.H.; Shin, Y.H.; Yoon, C.; Woo, J.S.; Kim, G.H. Effect of electron beam irradiation on developmental stages of Plutella xylostella (Lepidoptera: Plutellidae). J. Asia-Pac. Entomol 2011, 14, 243-247. [CrossRef]

18. Koo, H.N.; Yun, S.H.; Yoon, C.; Kim, G.H. Electron beam irradiation induces abnormal development and the stabilization of p53 protein of American serpetine leafminer, Liriomyza trifolii (Burgess). Radiat. Phys. Chem. 2012, 81, 86-92. [CrossRef]

19. Yun, S.H.; Kim, M.; Kim, H.; Lee, S.W.; Yoo, D.H.; Kim, H.K.; Koo, H.N.; Kim, G.H. Doses of electron beam and X-ray irradiation for inhibition of development and reproduction in four insect pests. Korean J. Appl. Entomol. 2014, 53, 391-398. [CrossRef]

20. Kim, J.; Chung, S.O.; Jang, M.; Jang, S.A.; Park, C.G. Developmental inhibition and DNA damage of Helicoverpa armigera Hubner (Lepidoptera: Noctuidae) by gamma radiation. Int. J. Radiat. Biol. 2015, 91, 827-832. [CrossRef] [PubMed]

21. Yun, S.H.; Koo, H.N.; Kin, H.K.; Yang, J.O.; Kim, G.H. X-ray irradiation as a quarantine treatment for the control of six insect pests in cut flower boxes. J. Asia-Pac. Entomol 2016, 19, 31-38. [CrossRef]

22. Cho, W.S.; Koo, H.N.; Yun, S.W.; Lee, J.S.; Jeong, D.H.; Kang, W.J.; Lee, S.J.; Kim, H.K.; Han, J.H.; Kwon, Y.D.; et al. Electron beam-induced sterility and inhibition of ovarian development in the Sakhalin pine longicorn, Monochamus saltuarius (Coleoptera: Cerambycidae). J. Econ. Entomol. 2018, 111, 725-731. [CrossRef] 
23. Koo, H.N.; Yun, S.H.; Kim, H.K.; Kim, G.H. Elucidation of molecular expression associated with abnormal development and sterility caused by electron beam irradiation in Spodoptera litura (F.) (Lepidoptera: Noctuidae). Int. J. Radiat. Biol. 2018, 95, 1-8. [CrossRef]

24. Cho, S.R.; Koo, H.N.; Shin, S.; Kim, H.K.; Park, J.H.; Yoon, Y.S.; Kim, G.H. Gamma-ray irradiation control of whitefly Bemisia tabaci (Hemiptera: Aleyrodidae) and Trialeurodes vaporariorum in the exportation of fresh strawberries. J. Econ. Entomol. 2019, 112, 1611-1617. [CrossRef]

25. Cho, S.R.; Shin, S.; Ahn, H.; Koo, H.N.; Kim, Y.; Kim, G.H. Control of whitefly (Hemiptera: Aleyrodidae), Trialeurodes vaporariorum, with electron beam and X-ray radiation of fresh strawberries for export. Insects. 2020, 11, 337. [CrossRef] [PubMed]

26. Fei, P.; El-Deiry, W.S. p53 and radiation responses. Oncogene 2003, 22, 5774-5783. [CrossRef]

27. SAS Institute. SAS User's Guide: Statistics; Version 9.4 ed.; SAS Institute: Cary, NC, USA, 2016.

28. Kim, J.; Jung, S.O.; Jang, S.A.; Kim, J.; Park, C.G. X-ray radiation and development inhibition of Helicoverpa armigera HÜber (Lepidoptera: Noctuidae). Radiat. Phys. Chem. 2015, 115, 148-152. [CrossRef]

29. Rananavare, H.D.; Harwalkar, M.R.; Rahalkar, G.W. Influence of modifying factors on induction of sterility and mating ability of potato tuberworm, Phthorimaea operculella (Zeller). J. Nucl. Agric. Biol. 1991, 20, 199-205.

30. Haiba, I.M. Disinfestation of different varieties of potato naturally or artificially infested by the potato tuber moth, $P$. operculella Zeller in the storage. J. Arb. Nucl. Sci. Appl. 1994, 27, 31-43.

31. Saour, G.; Makee, H.; Al-Oudat, M. Susceptibility of potato plants grown from tubers irradiated with stimulation doses of gamma irradiation to potato tuber moth, Phthorimaea operculella Zeller (Lep., Gelechiidae). J. Appl. Entomol. 1999, 123, 159-164. [CrossRef]

32. Haiba, I.M. Integration of ash and gamma-irradiation for controlling the potato tuber moth, P. operculella Zeller in storage. Bull. Ent. Soc. Egypt, Econ. Ser. 2000, 27, 78-107.

33. Mahto, R.; Mandal, S.K.; Chakraborty, P. Susceptibility of eggs, larvae and pupae of potato tuber moth, Phthorimaea operculella (Zeller) to ionizing radiation doses used for sprout inhibition in potatoes. J. Entomol. Res. 2012, 36, $201-206$.

34. Hasan, M.M.; Todoriki, S.; Miyanoshita, A.; Imamura, T. Detection of gamma radiation-induced DNA damage in maize weevil, Sitophilus zeamais Motschulsky (Coleoptera: Curculionidae) assessed using the comet assay. Int. J. Radiat. Biol. 2008, 84, 815-820. [CrossRef]

35. Imamura, T.; Todorikia, S.; Sotaa, N.; Nakakitaa, H.; Ikenagaa, H.; Hayashib, T. Effect of "soft-electron" (low-energy electron) treatment on three stored-product insect pests. J. Stored Prod. Res. 2004, 40, 169-177. [CrossRef]

36. Todoriki, S.M.; Hasan, A.; Miyanoshita, T.; Immamura, T.; Hayashi, T. Assessment of electron beam-induced DNA damage in larvae of chestnut weevil, Curculio sikkimensis (Heller) (Coleoptera: Curculionidae) using comet assy. Radiat. Phys. Chem. 2006, 75, 292-296. [CrossRef]

37. Yun, S.H.; Koo, H.N.; Kim, H.K.; Cho, S.; Kim, G.H. Effects of electron beam irradiation on six insect pests in different sections of flower boxes for export. J. Asia-Pac. Entomol. 2015, 18, 629-636. [CrossRef]

38. Kim, J.; Joo, Y.A.; Lee, Y.J.; Kim, J.; Jang, M.; Park, C.G. Small scale-up validation for ionizing radiations against Helicoverpa armigera larvae. J. Asia-Pac. Entomol. 2016, 19, 5-7. [CrossRef]

39. Park, J.S.; Jeong, S.Y.; Ahn, S.J.; Kim, I. Effects of gamma radiation on different development stages of the oriental tobacco budworm, Helicoverpa assulta (Lepidoptera: Noctuidae). Entomol. Res 2015, 45, 110-115. [CrossRef] 